Transcontinentales

continentales

Sociétés, idéologies, système mondial

Afrique plurielle

\title{
Amérique latine
}

\section{(2) OpenEdition \\ 12 Journals}

Édition électronique

URL : http://journals.openedition.org/transcontinentales/1491

DOI : 10.4000/transcontinentales. 1491

ISBN : 978-2-8218-1408-0

ISSN : 1775-397X

\section{Éditeur}

Editions de la maison des sciences de l'homme

\section{Édition imprimée}

Date de publication : 30 juin 2006

Pagination : 188

ISBN : 2200-92169-1

ISSN : 1950-1684

\section{Référence électronique}

"Amérique latine », Transcontinentales [En ligne], 2 | 2006, document 26, mis en ligne le 15 décembre 2012, consulté le 25 septembre 2020. URL : http://journals.openedition.org/transcontinentales/1491 ; DOI : https://doi.org/10.4000/transcontinentales.1491

Ce document a été généré automatiquement le 25 septembre 2020.

Tous droits réservés 


\section{Amérique latine} Matsigenka, Yanesha, Panama, Smithsonian Tropical Research Institute/ Lima, IFÉA, 2004,368 p.

12 TOMOEDA Hiroyasu, Tatsuhiko FUJI et Luis MILLONES, Entre dios y el diablo. Magia y poder en la costa norte del Peru, Lima, IFÉA, 2004, 209 p. 